\title{
Molecular cloning, expression analysis and assignment of the porcine tumor necrosis factor superfamily member 10 gene (TNFSF10) to SSC13q34 $\rightarrow$ q36 by fluorescence in situ hybridization and radiation hybrid mapping
}

\author{
E. Kemter, ${ }^{\text {a U. Philipp, }}{ }^{\text {b R. Klose, }}{ }^{a}$ H. Kuiper, ${ }^{b}$ M. Boelhauve, ${ }^{a}$ O. Distl, ${ }^{b}$ \\ E. Wolf, ${ }^{\text {a }}$ T. Leeb ${ }^{b}$ \\ a Institute for Molecular Animal Breeding and Biotechnology, Gene Center, Ludwig Maximilian University, Munich; \\ b Institute of Animal Breeding and Genetics, School of Veterinary Medicine Hannover, Hannover (Germany)
}

Manuscript received 15 September 2004; accepted in revised form for publication by M. Schmid 13 October 2004.

\begin{abstract}
We have cloned the complete coding region of the porcine TNFSF 10 gene. The porcine TNFSF 10 cDNA has an ORF of 870 nucleotides and shares $85 \%$ identity with human TNFSF 10 , and $75 \%$ and $72 \%$ identity with rat and mouse Tnfsf 10 coding sequences, respectively. The deduced porcine TNFSF 10 protein consists of 289 amino acids with the calculated molecular mass of $33.5 \mathrm{kDa}$ and a predicted $\mathrm{pI}$ of 8.15 . The amino acid sequence similarities correspond to 86, 72 and $70 \%$ when compared with human, rat and mouse sequences, respectively. Northern blot analysis detected TNFSF10-specific transcripts $(\sim 1.7 \mathrm{~kb})$ in various organs of a 10 -week-old
\end{abstract}

pig, suggesting ubiquitous expression. Real-time RT-PCR studies of various organs from fetal (days 73 and 98) and postnatal stages (two weeks, eight months) demonstrated developmental and tissue-specific regulation of TNFSF 10 mRNA abundance. The chromosomal location of the porcine TNFSF10 gene was determined by FISH of a specific BAC clone to metaphase chromosomes. This TNFSF10 BAC clone has been assigned to $\mathrm{SSC} 13 \mathrm{q} 34 \rightarrow \mathrm{q} 36$. Additionally, the localization of the TNFSF10 gene was verified by $\mathrm{RH}$ mapping on the porcine IMpRH panel.

Copyright @ 2005 S. Karger AG, Basel
TNF $\alpha$-related apoptosis-inducing ligand (TRAIL/Apo-2L) is encoded by the tumor necrosis factor superfamily member 10 gene (TNFSF 10). Currently over 40 distinct ligand-receptor systems of this superfamily are recognized in human. In pig, the positions of TNFSF $1 A$ and TNFSF $1 B$ were mapped to $7 \mathrm{p} 11 \rightarrow \mathrm{q} 11$ (Solinas et al., 1992). Sequence information of

\footnotetext{
This work was supported by the Graduate Program of the Ludwig Maximilian University Munich (to E.K.) and in parts by the Bayerische Forschungsstiftung (grants 219/96, 328/99, 464/01) and the Deutsche Forschungsgemeinschaft (FOR 535).

Database Accession No.: AJ786143, AJ786144, AY639873

Request reprints from Tosso Leeb, Institute of Animal Breeding

School of Veterinary Medicine Hannover

Buenteweg 17p, 30559 Hannover (Germany)

telephone: +49 5119538874 ; fax: +49 5119538582

e-mail: Tosso.Leeb@tiho-hannover.de
}

three other genes, TNFSF4-6, is available in public databases along with a growing number of porcine transcripts showing high homologies to human TNF ligand superfamily members. TRAIL has been shown to be important for the control of tumor growth and for modulation of the cellular immune system. An apoptosis-inducing effect of TRAIL was observed primarily in tumor cells and in Jurkat human T cells. This effect is initiated by binding of TRAIL to receptors TRAIL-R1 (DR4) and TRAIL-R2 (DR5), which signal apoptosis via their cytoplasmic death domains (Pan et al., 1997a, b; Sheridan et al., 1997). Other TRAIL binding proteins, TRAIL-R3 (DcR1), TRAIL-R4 (DcR2), and osteoprotegerin, lack functional death domains and have been discussed as decoy receptors (DegliEsposti et al., 1997; Marsters et al., 1997; Sheridan et al., 1997).

Recent studies have shown that TRAIL is involved in the mediation of cytotoxic effects of immune cells, including Tcells, NK cells, macrophages and dendritic cells. Thus it has \begin{tabular}{lll}
\hline KARGER & $\begin{array}{l}\text { Fax }+41613061234 \\
\text { E-mail karger@karger.ch } \\
\text { www.karger.com }\end{array}$ & ( ) 2005 S. Karger AG, Basel \\
1424-8581/05/1111-0074\$22.00/0
\end{tabular}
Accessible online at:

www. karger.com/cgr 
been suggested that TRAIL could play a role in suppressing tumor metastasis. This assumption was supported by the observation of increased susceptibility to tumor initiation and metastasis in TRAIL-deficient mice (Liu et al., 2001; Takeda et al., 2001; Cretney et al., 2002).

In addition to its anti-tumor effects, various immune modulatory mechanisms of TRAIL have been described. TRAIL is able to induce primary plasma cell apoptosis and to shorten the lifespan of neutrophils (Ursini-Siegel et al., 2002; Renshaw et al., 2003; Kamohara et al., 2004). Moreover TRAIL acts as a cell cycle inhibitor for T-cells independent of their differentiation status or antigen specificity (Song et al., 2000; Lunemann et al., 2002). Recently TRAIL was reported to inhibit the primarily T-cell mediated rejection of corneal allografts (Xie et al., 2003). Thus, expression of human TRAIL in transgenic pigs might be a strategy to protect pig tissues against cell-mediated rejection after xenotransplantation to primates (Klose et al., 2005). To further explore the feasibility of this approach, information on sequence similarity and expression levels of the endogenous TNFSF10 gene encoding TRAIL is necessary. Therefore, we cloned the porcine TNFSF 10 cDNA, determined TNFSF 10 mRNA levels in different tissues and at various stages of development, and mapped the porcine TNFSF10 gene to $\mathrm{SSC} 13 \mathrm{q} 34 \rightarrow \mathrm{q} 36$.

\section{Materials and methods}

Cloning and sequencing of the porcine TNFSF10 cDNA sequence PCR primers (TRAIL\#4/TRAIL867 and TRAIL\#7/TRAIL\#6; all primers used in this study are listed in Table 1) were designed based on the human, mouse and rat TNFSF 10/TnfSf10 cDNA sequences (DDBJ/EMBL/ GenBank database accession numbers U37518, U37522 and AY115578) and used to amplify partial sequences of the porcine TNFSF10 cDNA. TRAIL\#5 was used as gene-specific primer in $3^{\prime}$-RACE using the SMART ${ }^{\mathrm{TM}}$ RACE cDNA Amplification Kit (BD Clontech, Mountain View, CA) according to the manufacturer's instructions. 5'-RACE was performed using a standard protocol (Sambrook and Russell, 2001) and the gene-specific primers TRAIL\#12 and TRAIL\#13 as well as the adapter primers Ad and Ad20T. PCR products were cloned using the TOPO TA Cloning ${ }^{\circledR}$ Kit (Invitrogen, Karlsruhe, Germany) and sequenced.

\section{Quantitative RT-PCR analysis of TNFSF 10 expression}

Total RNA of liver, lung and kidney of fetuses and pigs of different ages was extracted using TRIZOL reagent (Invitrogen) following the manufacturer's instructions. RNA quality was checked by gel electrophoresis before and after DNase digestion. Reverse transcription was performed using $400 \mathrm{ng}$ total RNA, $3 \mu \mathrm{g}$ hexamer primers, $10 \mathrm{mM}$ DTT, 40 units RNaseOut (Invitrogen) and 200 units Superscript II reverse transcriptase (Invitrogen) at $42^{\circ} \mathrm{C}$ for $50 \mathrm{~min}$. After termination at $70^{\circ} \mathrm{C}$ for $15 \mathrm{~min}$, samples were stored at $-80^{\circ} \mathrm{C}$.

Primers for a housekeeping gene (H2A_se and H2A_as, Table 1) were designed from the bovine histone 2A $(H 2 A)$ sequence (accession NM_174809) and used as internal control. Primers TRAIL\#5 and TRAIL\#6 were used for the amplification of a TNFSF10 cDNA fragment (Table 1). Quantification of mRNA abundance was performed by real-time PCR detection using an ABI PRISM 7700 sequence detector (Applied Biosystems, Weiterstadt, Germany) and SybrGreen ${ }^{\circledR}$ as a double stranded DNA-specific fluorescent dye. Amplification mixes $(25 \mu \mathrm{l})$ contained $2 \mu \mathrm{l}$ cDNA, $12.5 \mu \mathrm{l}$ SybrGreen PCR Mix, $0.25 \mu \mathrm{l}$ IU AmpErase uracil $N$-glycosylase (all from Applied Biosystems), $1.5 \mu \mathrm{l}$ of each primer (300 nM finally), and $7.25 \mu \mathrm{l}$ water. The standard curve was performed using plasmids with the sequences of the selected genes, and six serial dilutions (1:5) were used for all selected genes ranging from 1 million to 320 copies. The abundance of TNFSF10 mRNAs was calculated using the standard curve method, with determination of PCR
Table 1. Primers used in this study

\begin{tabular}{lll}
\hline Primer & Orientation & Sequence $\left(5^{\prime}-3^{\prime}\right)$ \\
\hline TRAIL867 & reverse & TAA AAA GGC ${ }_{\text {TCC }}{ }_{\text {GAA A }}{ }_{\text {GAA A }}{ }_{G}$ CT GGC TTC \\
TRAIL \#5 & forward & TGG ACA AGC TAT CCT GAC CCT ATA C \\
TRAIL \#6 & reverse & CAC CTT GAT AGA TGG AAT AGA GTC C \\
TRAIL \#12 & reverse & TCA CAA ACT GAC GTA GCT GCC AC \\
TRAIL \#13 & reverse & TCA TCA GCA GTA TAG GGT CAG \\
AdT20 & forward & ATT GAA TTC TCT AGA ACG CGT CTC GAG (T) ${ }_{20}$ \\
Ad & forward & ATT GAA TTC TCT AGA ACG CGT CTC GAG \\
H2A_se & forward & TGC TGG TGG TGG TGT CAT TC \\
H2A_as & reverse & CCA GGC ATC CTT TAG ACA GTC TTC T \\
TNFSF10_F & forward & TCA ACC CAA AGG CTC AAC \\
TNFSF10_R & reverse & CAG TGC TGC CCT TTT CTC \\
\hline
\end{tabular}

amplification efficiency and normalization for H2A mRNA as the internal reference.

QPCR was started with $2 \mathrm{~min}$ at $50^{\circ} \mathrm{C}$ for AmpErase activation and $10 \mathrm{~min}$ at $95^{\circ} \mathrm{C}$ for denaturation. The program continued with 40 cycles of $15 \mathrm{~s}$ at $95^{\circ} \mathrm{C}$ and $30 \mathrm{~s}$ at $60^{\circ} \mathrm{C}$ and $30 \mathrm{~s}$ at $72^{\circ} \mathrm{C}$. Each assay included triplicates of cDNA.

Isolation and characterization of a genomic TNFSF 10 clone

A genomic DNA clone (RP44-472G15) of approximately $165 \mathrm{~kb}$ was isolated from the porcine RPCI-44 BAC library after screening high density BAC filters according to the RPCI protocols (http://www.chori.org/bacpac/). A ${ }^{32}$ P-labeled 279-bp PCR product from the porcine TNSF10 gene was used as probe. The PCR primers for this product were TNFSF10_F and TNFSF10_R (Table 1). DNA of the BAC clone RP44\#472G15 was isolated using the Qiagen plasmid midi kit (Qiagen, Hilden, Germany). BAC ends were sequenced with the ThermoSequenase kit (Amersham Biosciences, Freiburg, Germany) on a LI-COR 4200L-2 automated sequencer (MWG Biotech, Ebersberg, Germany). The end sequences were deposited under accessions AJ786143 and AJ786144 in the EMBL nucleotide database.

Fluorescence in situ hybridization (FISH) analysis

The porcine genomic BAC clone RP44-472G15 containing the porcine TNFSF10 gene was labeled with digoxigenin by nick translation using a Nick-Translations-Mix (Roche, Mannheim, Germany). FISH on GTGbanded pig chromosomes was performed using $750 \mathrm{ng}$ of digoxigenin-labeled BAC DNA. In this experiment $24 \mu \mathrm{g}$ sheared total porcine DNA and $10 \mu \mathrm{g}$ salmon sperm were used as competitors. After hybridization over night, signal detection was performed using a digoxigenin-FITC detection kit (Quantum Appligene, Heidelberg, Germany). The chromosomes were counterstained with DAPI and propidium iodide and embedded in antifade solution. Thirty metaphases that had previously been photographed were reexamined after hybridization with a Zeiss Axioplan 2 microscope equipped for fluorescence.

\section{Probe description:}

Probe name: RP44-472G15

Probe type: porcine genomic BAC clone

Insert size: $165 \mathrm{~kb}$

Vector: pTARBAC2

Proof of authenticity: DNA sequencing and gene-specific PCR

Gene reference of human TNFSF10: Wiley et al., 1995

\section{Radiation hybrid (RH) mapping}

The primer pair TNFSF10_F and TNFSF10_R developed for the amplification of the TNFSF 10 probe was also used for RH mapping. Amplification of the marker was done on the INRA-Minnesota Porcine Radiation Hybrid (IMpRH) panel (Yerle et al., 1998; Hawken et al., 1999) (http://imprh.toulouse.inra.fr/) as described previously (Leeb and Rohrer, 2002). The mapping tool at the IMpRH Server (Milan et al., 2000) was used for the mapping of this new marker relatively to markers previously mapped on the IMpRH panel. The order of markers already mapped on the first generation map is considered as known. The two point option of the RHMAP3.0 package (Lange et al., 1995) reveals two-point distances with flanking markers. 


\begin{abstract}
pig MAVMQTPGGPSPGQ----TCVLILIFTVLLQALCVALTYVYFTNELKQMQDKYSKSGIAC
human MAMMEVQGGPSLGQ----TCVLIVIFTVLLQSLCVAVTYVYFTNELKQMQDKYSKSGIAC

rat MASTGNLKGPSFSQHFTMTVICIVLLQVLLQALTVAVTYMYFNNEVKQLQDNYSKIGLAC

mouse MPSSGALKDLSFSQHFRMMVICIVLLQVLLQAVSVAVTYMYFTNEMKQLQDNYSKIGLAC

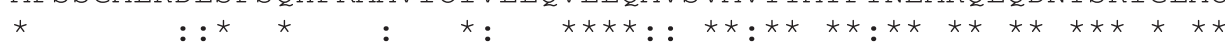

pig FLKEDDSFWDPTDDERMLSPCWQVKWQLRQFVRKMILRTYEETISTVSEKQQGIPHLERE

human FLKEDDSYWDPNDEESMNSPCWQVKWQLRQLVRKMILRTSEETISTVQEKQQNISPLVRE

rat FSKEDGDFWDSTDEGILNRPCLQVKRQLYQLIEEVTLRTFEKTISTVPEKQLSTPPLPRG

mouse FSKTDEDFWDSTDGEILNRPCLQVKRQLYQLIEEVTLRTFQDTISTVPEKQLSTPPLPRG

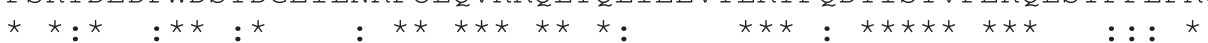

pig KGPQRVAAHITGTSRKRSTFPSLSSKYEKALGQKINSWESSRKGHSFLNNFHLRNGELVI

human RGPQRVAAHITGTRGRSNTLSSPNSKNEKALGRKINSWESSRSGHSFLSNLHLRNGELVI RRPQRVAAHITGITRRSNLALIPISKDGKTLGQKIETWESSRRGHSFLNHVHLRNGELVI GRPQKVAAHITGITRRSNSALIPISKDGKTLGQKIESWESSRKGHSFLNHVLFRNGELVI

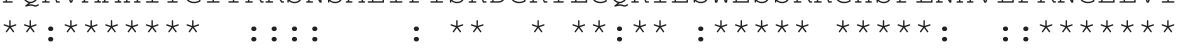

pig HQTGFYYISQTYFRFQEPEEILGTVSTEGNRKKNRQMIQYIYKWTSYPDPILLMKSARN

human HEKGFYYIYSQTYFRFQE--------EIKENTKNDKQMVQYIYKYTSYPDPILLMKSARN

rat QEEGLYYIYSQTYYRFKEAKEAS--KTVSKDGGRIKQMVQYIYKYTSYPDPILLMKSARN

mouse EQEGLYYIYSQTYFRFQEAEDAS--KMVSKDKVRTKQLVQYIYKYTSYPDPIVLMKSARN

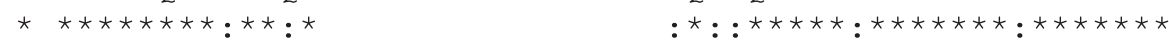

pig SCWSKDSEYGLYSIYQGGIFELKEDDRIFVSVTNEQLIDMDQEASFFGAFLIG

human SCWSKDAEYGLYSIYQGGIFELKENDRIFVSVTNEHLIDMDHEASFFGAFLVG

rat

SCWSREAEYGLYSIYQGGLFELKENDRIFVSVTNEHLMDLDHEASFFGA

mouse SCWSRDAEYGLYSIYQGGLFELKKNDRIFVSVTNEHLMDLDQEASFFGAFLIN

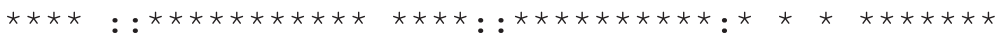

Fig. 1. Deduced amino acid sequence of porcine TNFSF10 and alignment to the human, rat, and mouse TNFSF10 proteins, respectively. The amino acid sequences for the human, rat, and mouse TNFSF10 were obtained from nucleotide sequences of the DDBJ/EMBL/GenBank database (human: U37518; rat: AY115578; mouse: U37522). Asterisks and colons under the aligned sequences indicate complete match and match among three species of four, respectively. The putative transmembrane anchor is underlined in the human sequence. A conserved cysteine residue that is assumed to mediate zinc binding is indicated by a rhom-
\end{abstract} bus.

\section{Results and discussion}

\section{Porcine TNFSF10 cDNA sequence}

To isolate the complete coding region of the porcine TNFSF10 gene, RACE experiments and PCR were performed. The cDNA has an ORF of 870 nucleotides. The sequence has been deposited in DDBJ/EMBL/GenBank under accession AY639873. The ORF has $85 \%$ identity to the TNFSF 10 nucleotide sequences of human TNFSF10, 75 and $72 \%$ identity to the nucleotide sequences of rat and mouse $T n f S f 10$, respectively. The deduced porcine TNFSF10 protein consists of 289 amino acids with a calculated molecular mass of $33.5 \mathrm{kDa}$ and a predicted $\mathrm{pI}$ of 8.15 . At the amino acid level the porcine TNFSF 10 protein shows $86 \%$ similarity to human TNFSF 10 and 72 or $70 \%$ to rat or mouse TNFSF10 amino acid sequences, respectively (Fig. 1). The putative transmembrane anchor for the porcine TNFSF10 protein comprises amino acids 18-28 similar to human. Amino acids 172-188 match the consensus sequence for the TNF type II membrane protein family. The domain for metal binding is highly conserved among pig, human, rat and mouse, with cysteine 230 (human) as the putative zinc binding amino acid, required for activity and trimerization of the TNFSF10 protein (Bodmer et al., 2000; Hymowitz et al., 2000). The high degree of amino acid identity between pig and human, especially in the C-terminal domain of the TNFSF 10 protein, suggests that the porcine protein might be able to interact with human TRAIL receptors.

\section{Expression of the porcine TNFSF10 gene}

The human gene for TNFSF10 is known to be ubiquitously expressed in a large variety of adult tissues (Wiley et al., 1995). To investigate expression of the porcine homolog, RT-PCR and Northern blot experiments were performed using RNA isolated from various tissues of a 10-week-old piglet. We detected TRAIL transcripts of approximately $1.7 \mathrm{~kb}$ in spleen, lung, liver, kidney, heart, testis, muscle and skin (data not shown). This suggested ubiquitous expression of TNFSF10 mRNA in pig. Highest expression levels were detected in spleen, liver and lung. In addition, we used quantitative RT-PCR to investigate TNFSF10 gene expression at two time points during fetal development (day 73 and 98) and postnatally in 2-week-old piglets and adult pigs ( 8 months). TNFSF10 transcript abundance in liver, lung and kidney was monitored in relation to histone $2 \mathrm{~A}$ transcripts, considering histone $2 \mathrm{~A}$ to be a constitu- 

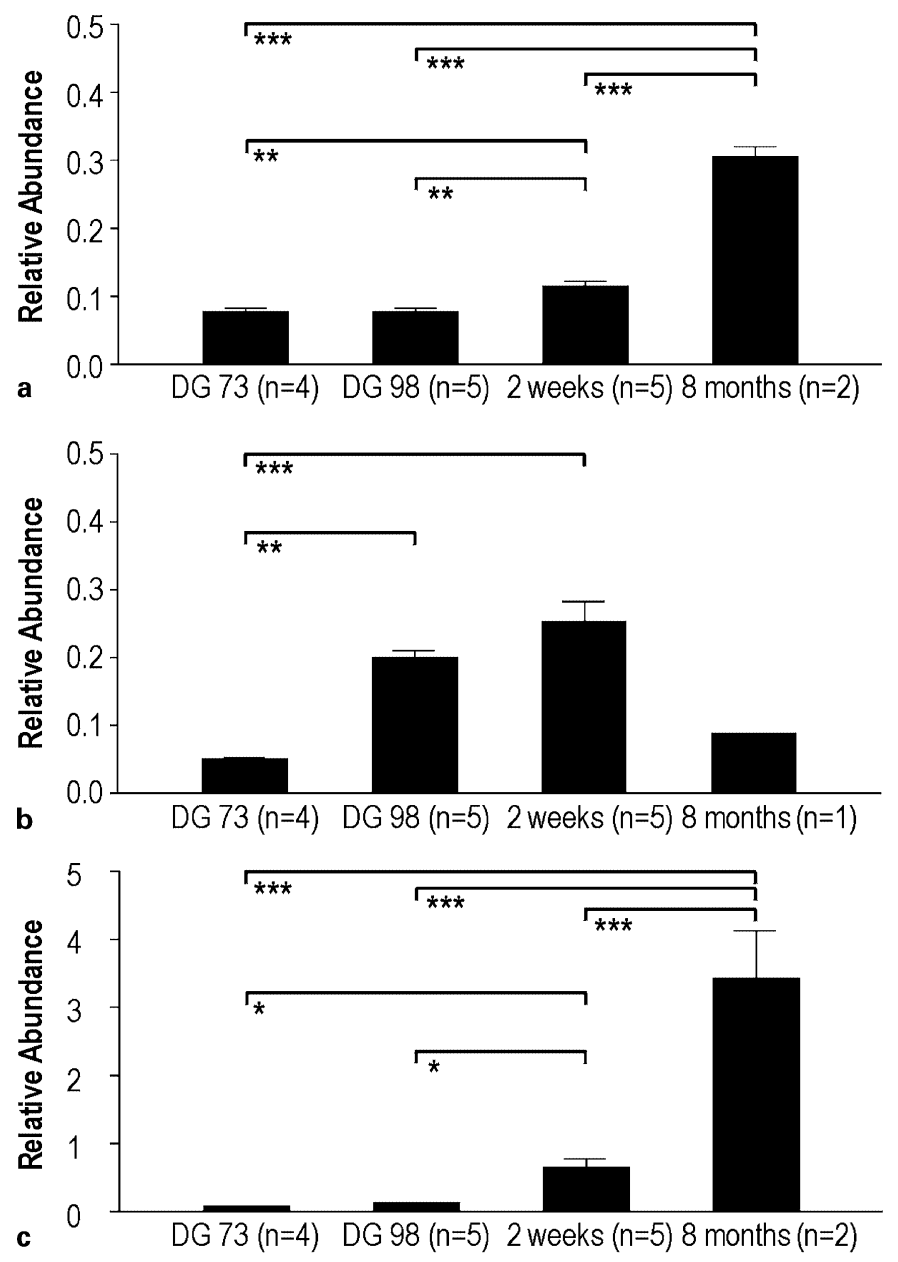

Fig. 2. Expression analysis of the porcine TNFSF 10 gene in fetal and adult tissues. Relative abundances were calculated using the standard curve method by dividing the copy numbers of TNFSF 10 mRNA by the copy numbers of $H 2 A$ mRNA. Bars represent means and standard deviations of the different developmental ages. DG: day of gestation; n: number of animals tested. (a) Kidney; (b) lung; (c) liver; $P$ values: ${ }^{*}<0.05,{ }^{* *}<0.01$, $* * *<0.0001$

tively expressed gene. We detected TNFSF10 transcripts in all tissue samples analyzed showing that expression was not restricted to postnatal life (Fig. 2). Whereas in kidneys and liver, normalized TNFSF10 expression did not change during fetal development and showed only moderate changes after birth, we observed an increase of TNFSF 10 mRNA levels in kidneys and liver of 8-month-old pigs (Fig. 2a, c). In contrast, expression levels in lungs seemed to be regulated during fetal development, showing a clear increase between mid- and late pregnancy. Postnatally, expression levels in lungs increased slightly above the high levels reached in late pregnancy, but declined in adult animals (Fig. 2b). The explicit increase of expression levels in fetal lung correlates with the saccular phase of lung development in pig (Rüsse and Sinowatz, 1991). Parallel to differentiation and growth of the bronchiolar and alveolar system, outgrowth of the vascular system in lung takes place. Since it was suggested that TNFSF10 plays an important role in endothelial

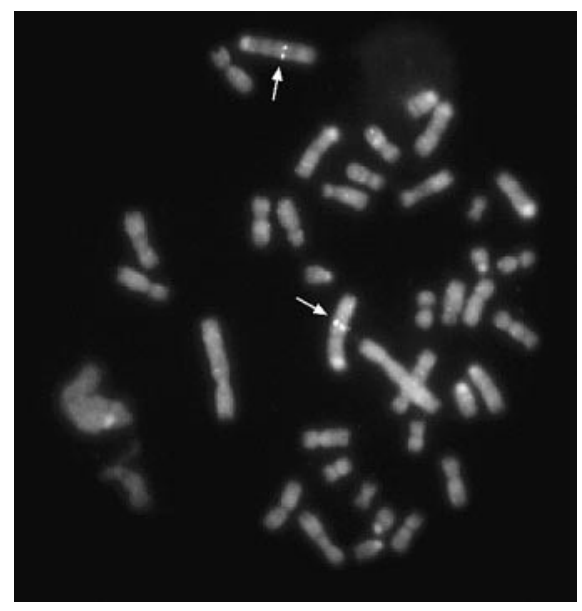

Fig. 3. Chromosome assignment of the porcine TNFSF10 gene by FISH analysis on a porcine metaphase spread. The digoxigenin labeled BAC clone RP44-472HG15 containing the porcine TNFSF10 gene was hybridized to GTG-banded metaphase chromosomes of a normal pig. Double signals indicated by arrows are visible on both chromosomes $13 \mathrm{q} 34 \rightarrow \mathrm{q} 36$. The chromosomes were counterstained with propidium iodide and subsequently identified by DAPI staining.

cell migration, vessel tube formation and extracellular matrix synthesis in lung fibroblasts (Yurovsky, 2003; Secchiero et al., 2004), TNFSF10 might be involved in lung tissue differentiation. Moreover, TNFSF 10 expression was located in the medial smooth cell layers of pulmonary arteries of mouse, rat and human (Gochuico et al., 2000; Spierings et al., 2004), as well as in the bronchial epithelium and alveolar septa in human (Spierings et al., 2004). Probably increased expression levels of TRAIL mRNA in pig are correlated with lung growth and differentiation. Accordingly, this might explain the low expression levels in fully grown animals observed in our analyses.

In liver, we observed continuous increase of TNFSF 10 transcript levels after birth as well as in adult animals (Fig. 2c). In mice up to $30-40 \%$ of liver natural killer (NK) cells were shown to express $T n f_{S} f 10$ constitutively (Ochi et al., 2004). If this holds true also in swine, increasing TNFSF 10 transcript levels might be due to a continuous raise in the TNFSF10 expressing cell population of the growing liver. Moreover, TNFSF10 expression on liver NK cells is upregulated by interferon $\gamma$ (Smyth et al., 2001). This cytokine is secreted among others by macrophages and mononuclear cells of the liver in response to infectious agents and bacterial endotoxins cleared from portal blood. Microbial colonization of the gut starts shortly after birth, so we suggest that TNFSF 10 expression levels rise strongly after activation of TNFSF10 expressing liver NK cells early in postnatal life. Later on, the immune status of the animals might be reflected in TNFSF 10 expression levels.

\section{Chromosomal assignment of the porcine TNFSF10 gene}

The porcine BAC clone RP44-472G15 has been retrieved from the RPCI-44 BAC library with a porcine TNSF 10 cDNA probe. Colony PCR indicated that the clone indeed contained the desired insert. Additional support for the correct identity of the BAC clone was gained by the analysis of the BAC end 
sequences. The T7 end sequence had a BLAST hit to the human genome (build 34.3) at $173.48 \mathrm{Mb}$ on HSA3 $(\mathrm{E}=$ $5 \cdot 10^{-13}$ ) while the SP6 end sequence had a BLAST hit at $173.68 \mathrm{Mb}$ on HSA3 $\left(\mathrm{E}=5 \cdot 10^{-13}\right)$. Thus the BLAST hits of the two porcine BAC end sequences bracketed the human TNFSF 10 gene at $173.54-173.56 \mathrm{Mb}$ on HSA3. The chromosomal location of the porcine TNFSF10 gene was determined to be at SSC13q34 $\rightarrow$ q36 by FISH of the BAC clone to metaphase chromosomes (Fig. 3). Additionally, the localization of the TNFSF 10 gene was verified by RH mapping on the porcine IMpRH panel. The RH results were submitted to the IMpRH database (http://imprh.toulouse.inra.fr). Two-point analysis (Wiley et al., 1995) revealed that TNFSF10 is linked to the marker IMpRH00891 on SSC13 with a distance of $18 \mathrm{cR}$ and a two-point Lod score of 14.89 . The RH results were thus consistent with the cytogenetic localization of TNFSF10 at
$\mathrm{SSC} 13 \mathrm{q} 34 \rightarrow \mathrm{q} 36$. The human TNFSF 10 ortholog is located on HSA3q26 (Wiley et al., 1995). The chromosomal locations of the rodent Tnfsf10 genes are MMU3A3 for the mouse and RNO2q24 for the rat (http://www.ncbi.nlm.nih.gov/mapview). These localizations correspond well to the synteny data of the porcine RH map (Rink et al., 2002).

\section{Acknowledgements}

The authors would like to thank Martine Yerle and Denis Milan for providing the IMpRH panel and excellent information on the porcine RH map (http://imprh.toulouse.inra.fr/). We would also like to thank Pieter de Jong and his lab for providing the RPCI-44 BAC library. We thank the staff of the pig unit, especially Barbara Keßler and Sonja Ewerling, for their help and collaboration.

\section{References}

Bodmer JL, Meier P, Tschopp J, Schneider P: Cysteine 230 is essential for the structure and activity of the cytotoxic ligand TRAIL. J Biol Chem 275:2063220637 (2000).

Cretney E, Takeda K, Yagita H, Glaccum M, Peschon JJ, Smyth MJ: Increased susceptibility to tumor initiation and metastasis in TNF-related apoptosis-inducing ligand-deficient mice. J Immunol 168:1356-1361 (2002)

Degli-Esposti MA, Dougall WC, Smolak PJ, Waugh JY, Smith CA, Goodwin RG: The novel receptor TRAIL-R4 induces NF-kappaB and protects against TRAIL-mediated apoptosis, yet retains an incomplete death domain. Immunity 7:813-820 (1997).

Gochuico BR, Zhang J, Ma BY, Marshak-Rothstein A Fine A: TRAIL expression in vascular smooth muscle. Am J Physiol Lung Cell Mol Physiol 278:L1045-L1050 (2000)

Hawken RJ, Murtaugh J, Flickinger GH, Yerle M, Robic A, Milan D, Gellin J, Beattie CW, Schook LB, Alexander LJ: A first-generation porcine whole-genome radiation hybrid map. Mamm Genome 10:824-830 (1999).

Hymowitz SG, O'Connell MP, Ultsch MH, Hurst A Totpal K, Ashkenazi A, de Vos AM, Kelley RF: A unique zinc-binding site revealed by a high-resolution X-ray structure of homotrimeric Apo2L/ TRAIL. Biochemistry 39:633-640 (2000)

Kamohara H, Matsuyama W, Shimozato O, Abe K, Galligan C, Hashimoto S, Matsushima K, Yoshimura $\mathrm{T}$ : Regulation of tumour necrosis factorrelated apoptosis-inducing ligand (TRAIL) and TRAIL receptor expression in human neutrophils. Immunology 111:186-194 (2004).

Klose R, Kemter E, Bedke T, Bittmann I, Keßler B, Endres R, Pfeffer K, Schwinzer R, Wolf E: Expression of biologically active TRAIL in transgenic pigs. Transplantation, accepted (2005).

Lange K, Boehnke M, Cox DR, Lunetta KL: Statistical methods for polyploid radiation hybrid mapping. Genome Res 5:136-150 (1995).

Leeb T, Rohrer GA: Characterization and chromosome assignment of the porcine $A H C Y$ gene for S-adenosylhomocysteine hydrolase. Cytogenet Genome Res 97:116-119 (2002).

Liu S, Yu Y, Zhang M, Wang W, Cao X: The involvement of TNF-alpha-related apoptosis-inducing ligand in the enhanced cytotoxicity of IFN-betastimulated human dendritic cells to tumor cells. J Immunol 166:5407-5415 (2001).
Lunemann JD, Waiczies S, Ehrlich S, Wendling U, Seeger B, Kamradt T, Zipp F: Death ligand TRAIL induces no apoptosis but inhibits activation of human (auto)antigen-specific T cells. J Immunol 168:4881-4888 (2002).

Marsters SA, Sheridan JP, Pitti RM, Huang A, Skubatch M, Baldwin D, Yuan J, Gurney A, Goddard AD, Godowski P, Ashkenazi A: A novel receptor for Apo2L/TRAIL contains a truncated death domain. Curr Biol 7:1003-1006 (1997).

Milan D, Hawken R, Cabau C, Leroux S, Genet C, Lahbib Y, Tosser G, Robic A, Hatey F, Alexander L, Beattie C, Schook L, Yerle M, Gellin J: IMpRH server: an RH mapping server available on the Web. Bioinformatics 16:558-559 (2000).

Ochi M, Ohdan H, Mitsuta H, Onoe T, Tokita D, Hara H, Ishiyama K, Zhou W, Tanaka Y, Asahara T: Liver NK cells expressing TRAIL are toxic against self hepatocytes in mice. Hepatology 39:13211331 (2004).

Pan G, Ni J, Wei YF, Yu G, Gentz R, Dixit VM: An antagonist decoy receptor and a death domain-containing receptor for TRAIL. Science 277:815-818 (1997a).

Pan G, O'Rourke K, Chinnaiyan AM, Gentz R, Ebner R, Ni J, Dixit VM: The receptor for the cytotoxic ligand TRAIL. Science 276:111-113 (1997b).

Renshaw SA, Parmar JS, Singleton V, Rowe SJ, Dockrell DH, Dower SK, Bingle CD, Chilvers ER, Whyte MK: Acceleration of human neutrophil apoptosis by TRAIL. J Immunol 170:1027-1033 (2003).

Rink A, Santschi EM, Eyer KM, Roelofs B, Hess M, Godfrey M, Karajusuf EK, Yerle M, Milan D, Beattie CW: A first-generation EST RH comparative map of the porcine and human genome. Mamm Genome 13:578-587 (2002)

Rüsse I, Sinowatz F: Lehrbuch der Embryologie der Haustiere (Parey Verlag, Berlin 1991)

Sambrook J, Russell DW: Molecular Cloning $3^{\text {rd }}$ ed (Cold Spring Harbor Laboratory Press, Cold Spring Harbor 2001).

Secchiero P, Zerbinati C, Rimondi E, Corallini F, Milani D, Grill V, Forti G, Capitani S, Zauli G: TRAIL promotes the survival, migration and proliferation of vascular smooth muscle cells. Cell Mol Life Sci 61:1965-1974 (2004).

Sheridan JP, Marsters SA, Pitti RM, Gurney A, Skubatch M, Baldwin D, Ramakrishnan L, Gray CL, Baker K, Wood WI, Goddard AD, Godowski P, Ashkenazi A: Control of TRAIL-induced apoptosis by a family of signaling and decoy receptors. Science 277:818-821 (1997).
Smyth MJ, Cretney E, Takeda K, Wiltrout RH, Sedger LM, Kayagaki N, Yagita H, Okumura K: Tumor necrosis factor-related apoptosis-inducing ligand (TRAIL) contributes to interferon gamma-dependent natural killer cell protection from tumor metastasis. J Exp Med 193:661-670 (2001).

Solinas S, Pauli U, Kuhnert P, Peterhans E, Fries R: Assignment of the porcine tumour necrosis factor alpha and beta genes to the chromosome region 7 p11-q11 by in situ hybridization. Anim Genet 23:267-271 (1992).

Song K, Chen Y, Goke R, Wilmen A, Seidel C, Goke A, Hilliard B, Chen Y: Tumor necrosis factor-related apoptosis-inducing ligand (TRAIL) is an inhibitor of autoimmune inflammation and cell cycle progression. J Exp Med 191:1095-1104 (2000).

Spierings DC, de Vries EG, Vellenga E, van den Heuvel FA, Koornstra JJ, Wesseling J, Hollema H, de Jong $\mathrm{S}$ : Tissue distribution of the death ligand TRAIL and its receptors. J Histochem Cytochem 52:821831 (2004).

Takeda K, Hayakawa Y, Smyth MJ, Kayagaki N, Yamaguchi N, Kakuta S, Iwakura Y, Yagita H, Okumura K: Involvement of tumor necrosis factorrelated apoptosis-inducing ligand in surveillance of tumor metastasis by liver natural killer cells. Nat Med 7:94-100 (2001).

Ursini-Siegel J, Zhang W, Altmeyer A, Hatada EN, Do RK, Yagita H, Chen-Kiang S: TRAIL/Apo-2 ligand induces primary plasma cell apoptosis. J Immunol 169:5505-5513 (2002).

Wiley SR, Schooley K, Smolak PJ, Din WS, Huang CP, Nicholl JK, Sutherland GR, Smith TD, Rauch C, Smith CA: Identification and characterization of a new member of the TNF family that induces apoptosis. Immunity 3:673-682 (1995).

Xie L, Shi W, Guo P: Roles of tumor necrosis factorrelated apoptosis-inducing ligand in corneal transplantation. Transplantation 76:1556-1559 (2003).

Yerle M, Pinton P, Robic A, Alfonso A, Palvadeau Y, Delcros C, Hawken R, Alexander L, Beattie C, Schook L, Milan D, Gellin J: Construction of a whole-genome radiation hybrid panel for highresolution gene mapping in pigs. Cytogenet Cell Genet 82:182-188 (1998).

Yurovsky VV: Tumor necrosis factor-related apoptosisinducing ligand enhances collagen production by human lung fibroblasts. Am J Respir Cell Mol Biol 28:225-231 (2003). 